\title{
Putting the rise of the Inca Empire within a climatic and land management context
}

\author{
A. J. Chepstow-Lusty ${ }^{1,2}$, M. R. Frogley ${ }^{3}$, B. S. Bauer ${ }^{4}$, M. J. Leng ${ }^{5}$, K. P. Boessenkool ${ }^{6}$, C. Carcaillet $^{2,7}$, A. A. Ali ${ }^{2}$, and \\ A. Gioda ${ }^{8}$ \\ ${ }^{1}$ Institut Français d'Etudes Andines (IFEA), Lima, Peru \\ ${ }^{2}$ Centre for Bio-Archaeology and Ecology, Université Montpellier 2, Montpellier, France \\ ${ }^{3}$ Department of Geography, University of Sussex, Brighton, UK \\ ${ }^{4}$ Department of Anthropology, The University of Illinois at Chicago, Illinois, USA \\ ${ }^{5}$ NERC Isotope Geoscience Laboratory, Nottingham, UK \\ ${ }^{6}$ School of Earth, Ocean and Planetary Sciences, University of Cardiff, Cardiff, UK \\ ${ }^{7}$ Paleoenvironments and Chronoecology, Institut de Botanique, Montpellier, France \\ ${ }^{8}$ Hydrosciences, IRD, Lima, Peru
}

Received: 30 January 2009 - Published in Clim. Past Discuss.: 4 March 2009

Revised: 7 July 2009 - Accepted: 11 July 2009 - Published: 22 July 2009

\begin{abstract}
The rapid expansion of the Inca from the Cuzco area of highland Peru (ca. AD 1400-1532) produced the largest empire in the New World. Although this meteoric growth may in part be due to the adoption of innovative societal strategies, supported by a large labour force and a standing army, we argue that it would not have been possible without increased crop productivity, which was linked to more favourable climatic conditions. Here we present a multi-proxy, high-resolution 1200-year lake sediment record from Marcacocha, located $12 \mathrm{~km}$ north of Ollantaytambo, in the heartland of the Inca Empire. This record reveals a period of sustained aridity that began from AD 880 , followed by increased warming from AD 1100 that lasted beyond the arrival of the Spanish in AD 1532. These increasingly warmer conditions would have allowed the Inca and their immediate predecessors the opportunity to exploit higher altitudes (post-AD 1150) by constructing agricultural terraces that employed glacial-fed irrigation, in combination with deliberate agroforestry techniques. There may be some important lessons to be learnt today from these strategies for sustainable rural development in the Andes in the light of future climate uncertainty.
\end{abstract}

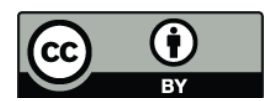

Correspondence to: A. Chepstow-Lusty (a.lusty@aliceadsl.fr)

\section{Introduction}

Through the use of regional-scale, multidisciplinary studies it is becoming increasingly evident that many prehistoric South American cultures were highly adaptable and able to ensure food security even under sustained periods of harsh climatic conditions. For example, immense, state level coastal societies such as the Moche (ca. AD 200-600) flourished in arid regions by developing sophisticated irrigation technologies to cope with extremes of water availability (Bawden, 1996). Highland cultures, on the other hand, not only had to deal with seasonal water supplies, but also had to combat large temperature ranges and steep terrain. A variety of innovative coping-strategies were therefore developed to maximise land-use and reduce soil erosion. These included the use of raised field systems by the Tiwanaku (ca. AD 5001100) (Kolata 1996; Erickson 1999, 2000) and constructing major terracing and irrigation systems by the Wari (AD 5001000) (Williams, 2006).

The Inca of the south-central Andes were also able to develop a range of landscape-scale practices across a range of agro-ecological zones to support the growing numbers of individuals subsumed under their political control. Whilst these practices were in some cases innovative, some were built on already-proven, sustainable techniques developed by previous societies (including the Wari). After a prolonged period of cultural development (ca. AD 1100-1400) the Inca rapidly expanded beyond their heartland region of the Cuzco

Published by Copernicus Publications on behalf of the European Geosciences Union. 
Valley (Bauer, 2004). By the time of European contact in 1532 they had become the largest empire to develop in the Americas, controlling a region stretching from what is today northern Ecuador to central Chile and supporting a population of more than 8 million. While the factors involved in their sudden collapse under the stress of the Spanish invasion, including the introduction of new diseases and civil wars have been well documented (Hemming, 1970), relatively little scholarly attention has been focused on the rapid rise of the Inca as a pan-Andean power. Although part of the reason behind this expansion has been attributed to the development of new economic institutions and revolutionary strategies of political integration (e.g. Covey, 2006), these social advances had to be underpinned by the ability to generate agricultural surplus that could sustain large populations, including the standing armies necessary for wide-ranging military campaigns.

Long before the Inca state developed, much of the central Andes was occupied by the Ayacucho-based Wari state (ca. AD 500-1000) and the Lake Titicaca-centred Tiwanauku state (ca. AD 500-1100). It is widely suggested that their declines were accelerated by worsening environmental conditions that decreased opportunities for agrarian intensification (Kolata, 1996; Williams, 2002, 2006; Bauer and Kellett, 2009). At around AD 1000, many lower elevation settlements in this region were abandoned and local populations became concentrated in newly constructed, defensibly-positioned sites located along high ridges. This dramatic settlement shift is generally thought to reflect a change from reliance on lower valley terrace (Wari) and raised field systems (Tiwanaku) to more diversified agropastoral economies. These agro-pastoral economies would have served as an effective risk-reduction subsistence strategy in the wake of widespread demographic, settlement and environmental change (Stanish, 2003; Arkush, 2006, 2008).

In the Cuzco region, the decline of the Wari ushered in a period of regional development with the initiation of the Inca state that later culminated in a relatively brief yet significant period of imperial expansionism (Bauer, 2004). Documenting in detail the environmental backdrop against which the Inca expanded their influence and power enhances our understanding of the social, political and economic challenges that they faced. One of the difficulties in achieving this, however, is that the earlier and more substantive part of the rise of the Inca took place over several centuries; a longer-term environmental perspective is therefore needed to understand the social and ecological contexts in which this development took place. In this study, therefore, we provide a detailed synthesis of a 1200-year palaeoenvironmental dataset derived from a climatically-sensitive, sedimentary sequence located in the Inca heartland. New geochemical $\left(\mathrm{C} / \mathrm{N}\right.$ and $\left.\delta^{13} \mathrm{C}\right)$ and floral (plant macrofossil, macrocharcoal and Myriophyllum pollen) proxy data, chosen for their ability to reflect both palaeoclimatic and anthropogenic change, are combined here for the first time with existing palynological, faunal and sedi-
Table 1. ${ }^{210} \mathrm{~Pb}$ dates for Marcacocha (adapted from ChepstowLusty et al., 2007). Determinations followed Flynn et al. (1968).

\begin{tabular}{|c|c|}
\hline Depth $(\mathrm{cm})$ & Calendar date \\
\hline $0-2$ & AD $1991 \pm 0.1$ \\
\hline $10-12$ & AD $1958 \pm 0.1$ \\
\hline $18-20$ & AD $1926 \pm 0.4$ \\
\hline $27-29$ & AD $1918 \pm 0.5$ \\
\hline $39-41$ & AD $1907 \pm 0.4$ \\
\hline $47-49$ & AD $1905 \pm 2.9$ \\
\hline $50-51$ & AD $1845 \pm 8.3$ \\
\hline
\end{tabular}

mentological records from the sequence, in order to establish a palaeoenvironmental framework against which human responses can be assessed.

\section{Site selection}

The best continuous, multi-proxy palaeoenvironmental archive from the Cuzco region is the 4200-year record derived from the lake site of Marcacocha (Chepstow-Lusty et al., 1996, 1998, 2003). Located within the Patacancha Valley, some $12 \mathrm{~km}$ north of both the major Inca settlement of Ollantaytambo and the Urubamba River, Marcacocha $\left(13^{\circ} 13^{\prime} \mathrm{S}\right.$, $72^{\circ} 12^{\prime} \mathrm{W}, 3355 \mathrm{~m}$ above sea-level [a.s.1.]) is a small (ca. $40 \mathrm{~m}$ diameter) circular, in-filled lake set within a larger basin (Fig. 1). The surrounding slopes constitute an ancient, anthropogenically-modified landscape, being extensively covered with Inca and pre-Inca agricultural terraces (Fig. 2). The in-filled lake site is separated from the Patacancha River by the promontory of Huchuy Aya Orqo, which contains stratified archaeological deposits that range from the Early Horizon period (ca. $800 \mathrm{BC}$ ) to Inca times (Kendall and Chepstow-Lusty, 2006). Today, the flat area adjacent to the in-filled lake provides space for minor potato cultivation and is used for grazing cattle, sheep, goats and horses. In the past, the site was also important for pasturing camelids, owing to its location along a former trans-Andean caravan route that linked the Amazonian selva in the east to the main western highland trading centres. Because the Patacancha River is fed partially by melt-water, it flows throughout the year, which may explain why the basin always remains wet despite a markedly seasonal climate. The constancy of the river is likely to have been a significant factor in ensuring both the long-term occupation of the site and also the exceptional preservation of the highly organic sediments and the faunal/floral remains they contain.

In 1993, an $8.25 \mathrm{~m}$ stratigraphically continuous sediment core that spans the last 4200 years was recovered from the centre of the basin for high-resolution palaeoecological analysis (Chepstow-Lusty et al., 1996, 1998, 2003). The chronology for the sequence was derived from seven ${ }^{210} \mathrm{~Pb}$ dates 
Table 2. Bulk radiocarbon dates from Marcacocha (adapted from Chepstow-Lusty et al., 2007). Calibration was carried out using the SHCal04 dataset (McCormac et al., 2004) in conjunction with version 5.0 of the CALIB calibration program (Stuiver and Reimer, 1993) and are cited as years before present (AD 1950).

\begin{tabular}{|c|c|c|c|c|c|}
\hline $\begin{array}{l}\text { Depth } \\
(\mathrm{cm})\end{array}$ & $\begin{array}{l}\text { Laboratory } \\
\text { Reference }\end{array}$ & $\begin{array}{l}{ }^{14} \mathrm{C} \text { age } \\
(\mathrm{yr} \mathrm{BP})\end{array}$ & $\begin{array}{l}\text { Median } \\
\text { calendar date }\end{array}$ & & Calibrated date \\
\hline $101-102$ & $\begin{array}{l}\text { Beta } \\
190482\end{array}$ & $400 \pm 40$ & AD 1540 & $\begin{array}{l}1 \sigma \\
2 \sigma\end{array}$ & $\begin{array}{l}\text { AD 1458-AD } 1510(54 \%) \\
\text { AD 1554-AD } 1556(1 \%) \\
\text { AD 1574-AD } 1621(45 \%) \\
\text { AD 1454-AD } 1626(100 \%)\end{array}$ \\
\hline $115-123$ & Q-2917 & $620 \pm 50$ & AD 1360 & $\begin{array}{l}1 \sigma \\
2 \sigma\end{array}$ & $\begin{array}{l}\text { AD 1315-AD } 1357(52 \%) \\
\text { AD 1381-AD } 1419(48 \%) \\
\text { AD } 1295-A D 1437(100 \%)\end{array}$ \\
\hline $210-218$ & Q-2918 & $1460 \pm 50$ & AD 630 & $\begin{array}{l}1 \sigma \\
2 \sigma\end{array}$ & $\begin{array}{l}\text { AD 568-AD } 678(100 \%) \\
\text { AD 440-AD } 485(3 \%) \\
\text { AD 537-AD } 775(97 \%)\end{array}$ \\
\hline $310-318$ & Q-2919 & $1805 \pm 50$ & AD 280 & $\begin{array}{l}1 \sigma \\
2 \sigma\end{array}$ & $\begin{array}{l}\text { AD 138-AD } 199(20 \%) \\
\text { AD 206-AD } 403(80 \%) \\
\text { AD 30-AD } 37(1 \%) \\
\text { AD 51-AD } 543(99 \%)\end{array}$ \\
\hline $478-486$ & Q-2920 & $2245 \pm 50$ & BC 240 & $\begin{array}{l}1 \sigma \\
2 \sigma\end{array}$ & $\begin{array}{l}\text { BC } 384-\text { BC } 160(95 \%) \\
\text { BC } 133-\text { BC } 117(5 \%) \\
\text { BC } 479-\text { BC } 470(<1 \%) \\
\text { BC } 414-\text { BC } 33(99 \%) \\
\text { BC } 36-\text { BC } 52(<1 \%)\end{array}$ \\
\hline $610-618$ & Q-2921 & $3650 \pm 60$ & BC 1960 & $\begin{array}{l}1 \sigma \\
2 \sigma\end{array}$ & $\begin{array}{l}\text { BC } 21374-\text { BC } 1754(100 \%) \\
\text { BC } 2430-\text { BC } 2425(<1 \%) \\
\text { BC 2401-BC } 2381(<1 \%) \\
\text { BC 2348-BC } 1607(99 \%) \\
\text { BC } 1572-\text { BC } 1559(<1 \%) \\
\text { BC } 1548-\text { BC } 1540(<1 \%)\end{array}$ \\
\hline
\end{tabular}

(Table 1) and six radiocarbon dates (Table 2). Confirmation of the sensitivity of the site to palaeoclimatic change comes from sub-centennial pollen analysis of the sequence, which documents the lake-level response to regional precipitation changes and records a series of aridity episodes broadly corresponding with regional cultural transitions indicated by an independently-derived archaeological chronology (Fig. 3) (Chepstow-Lusty et al., 2003; Bauer, 2004). Other previous work carried out on the sequence includes an assessment of basic sedimentological characteristics (such as carbonate, organic and non-organic content) and, from the top $1.9 \mathrm{~m}$, an analysis of oribatid mite remains, thought to be an indirect indicator of large domestic herbivore densities in the catchment over the past ca. 1200 years (Chepstow-Lusty et al., 2007).

\subsection{New proxies}

In order to help understand potential links between past environmental and cultural change in the region, the existing palaeoenvironmental datasets from Marcacocha were assessed alongside new, complementary proxy analyses.
Plant macrofossils can be extremely useful in determining local environmental conditions (see review by Birks, 2001). The calcified remains of charophyte oogonia (gyrogonites), for example, are generally regarded as aquatic indicators of clear, shallow water that is often nutrient-poor (Krause, 1981; Kufel and Kufel, 2001). Their numbers decline when water becomes polluted, turbid or eutrophic (Krause, 1981), such as when the water body is impacted regularly by high numbers of livestock. Seeds from the Juncaceae (reed) family, on the other hand, are indicative of damp, marginal aquatic environments and often, poor quality soils. As water levels fall and the lake begins to in-fill with sediment, these emergent macrophytes encroach from the margins until they completely cover the surface of the former lake (as is the current situation with Marcacocha today).

Technically classified as another type of plant macrofossil, charcoal remains can be used in reconstructing fire frequency histories and are often indicative of anthropogenic activity in the immediate landscape (e.g. Whitlock and Larsen, 2001). The relatively large macrocharcoal particles analysed here $(>125 \mu \mathrm{m})$ are of a sufficient size to provide an indicator of localized burning (i.e. within $100-200 \mathrm{~m}$ of the lake), having 


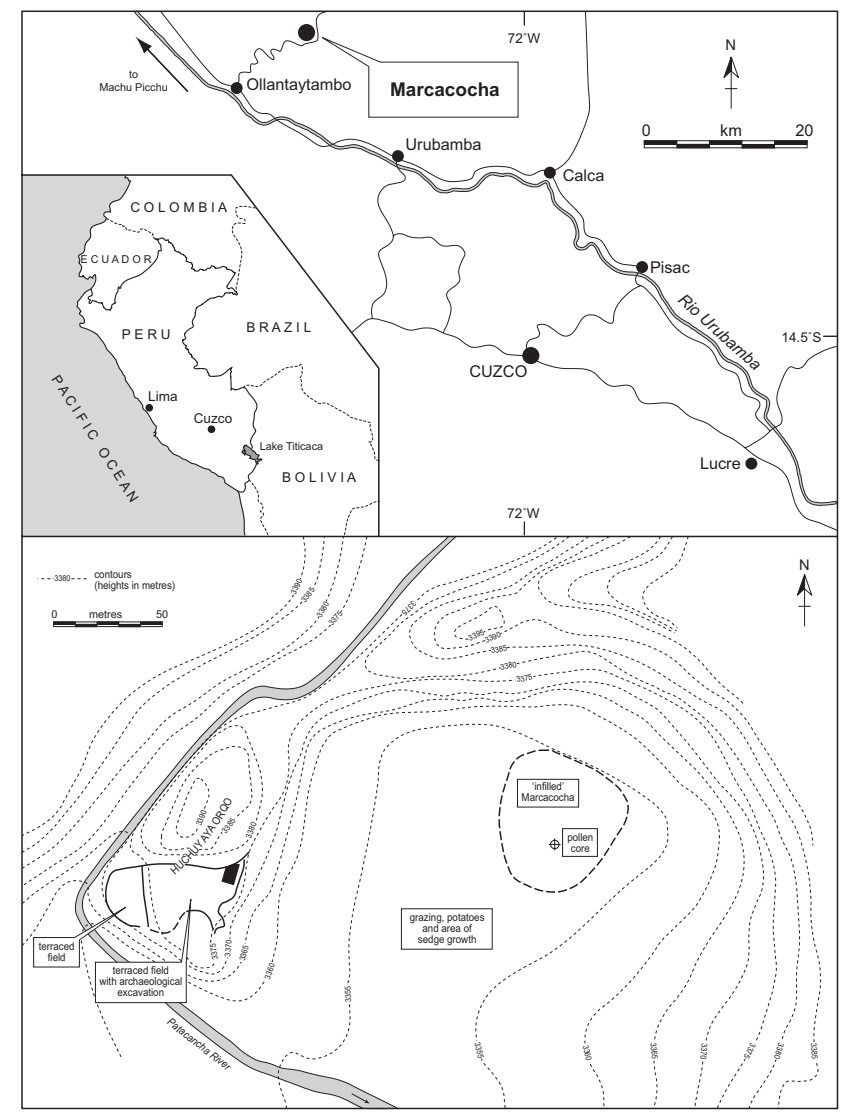

Fig. 1. Location maps.

either been washed in by surface run-off or blown in from the immediate catchment.

The value of palynology in helping to determine environmental and anthropogenic change across a landscape is well documented. Pollen from the entire Marcacocha sequence has been analysed previously (Chepstow-Lusty et al., 1996, 1998, 2003), although the Myriophyllum data have not hitherto been published. Myriophyllum pollen represents a group of hardy aquatic plants (the watermilfoils) that favour shallow, nutrient-rich conditions and are often associated with human impact and disturbance (e.g. Smith and Barko, 1990).

Organic matter is an important constituent of lake sediments, the primary source of which is the residue of former biota (mostly plants) located in and around the lake itself (Meyers and Teranes, 2001). Although the various processes of sedimentation and diagenesis (especially degradation) will both alter the geochemical signature and reduce the concentration of organic matter ultimately preserved in the lake deposits, analyses can often still distinguish between allochthonous and autochthonous sources and determine the nature of that original material (e.g. Hodell and Schelske, 1998). Carbon/nitrogen ratios $(\mathrm{C} / \mathrm{N})$ and $\delta^{13} \mathrm{C}$ data obtained from organic matter are especially useful in providing an insight into the amount and source of organic material entering

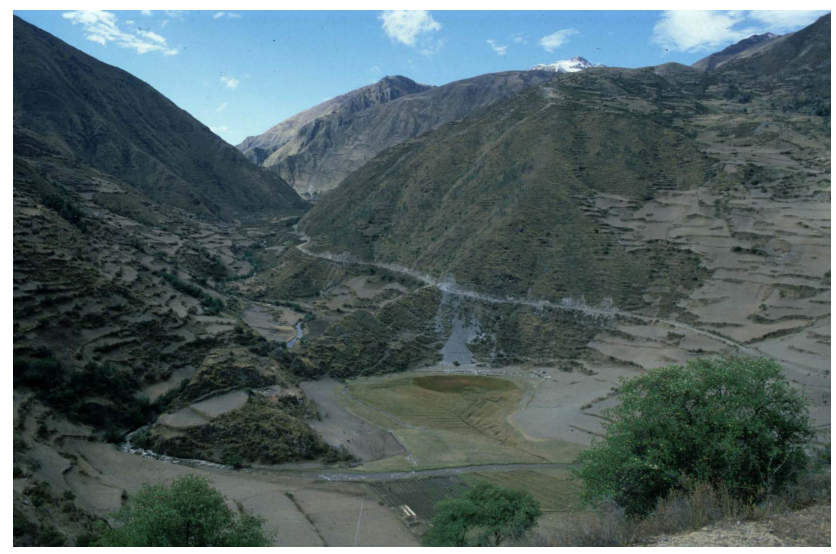

Fig. 2. General view north-eastwards up the Patacancha Valley over the infilled lake of Marcacocha (defined by the circle of Juncaceae vegetation), surrounded by Inca and pre-Inca terraces. The promontory on which the archaeological site of Huchuy Aya Orqo is found lies behind Marcacocha and projects from the eastern side of the valley towards the Patacancha River, which flows throughout the year. Notice the concentration of pasture adjacent to Marcacocha and the proximity of the Inca road $<50 \mathrm{~m}$ to the east, which connected the selva with the sierra. The herring-bone shaped drainage furrows to the south of the in-filled lake are relicts from past potato production. The maize fields are set further back, beyond the immediate areas liable to flooding. Ollantaytambo in the Sacred Valley is $12 \mathrm{~km}$ downstream, behind the viewer. Photograph taken in August 1996, during the height of the dry season.

a lake system (e.g. Talbot and Lærdal, 2000). If supported by additional plant macrofossil evidence (as in this study), this information can help to document catchment vegetation changes through time (Meyers and Teranes, 2001).

Organic matter derived from aquatic phytoplankton (C3 algae) predominantly has $\mathrm{C} / \mathrm{N}$ ratios of between 4 and 10 , whereas that from both $\mathrm{C} 3$ and $\mathrm{C} 4$ terrestrial plants commonly has ratios in excess of 20 (Meyers, 1994). Lacustrinederived sedimentary organic matter with $\mathrm{C} / \mathrm{N}$ ratios of between 10 and 20 would normally represent a mixture of aquatic and terrestrial plant material (Meyers, 1994). Although the degradation of organic matter during sedimentation and diagenesis can ultimately affect $\mathrm{C} / \mathrm{N}$ ratios (e.g. Sarazin et al., 1992; Meyers et al., 1995), the changes are unlikely to result in shifts large enough to obscure the terrestrial/aquatic nature of the source material (Meyers and Teranes, 2001).

Organic matter-derived $\delta^{13} \mathrm{C}$ values are also useful in assessing palaeoenvironmental changes both within the lake and its catchment. Principal controls on these values include the isotopic composition of inflowing groundwaters (that will themselves have been influenced by the composition and degradation of catchment soils and nature of the vegetation), the rate of in-lake atmospheric $\mathrm{CO}_{2}$ exchange, and the rates of photosynthesis and respiration by plants within the water column (e.g Brenner et al., 1999; Leng and Marshall, 2004). 


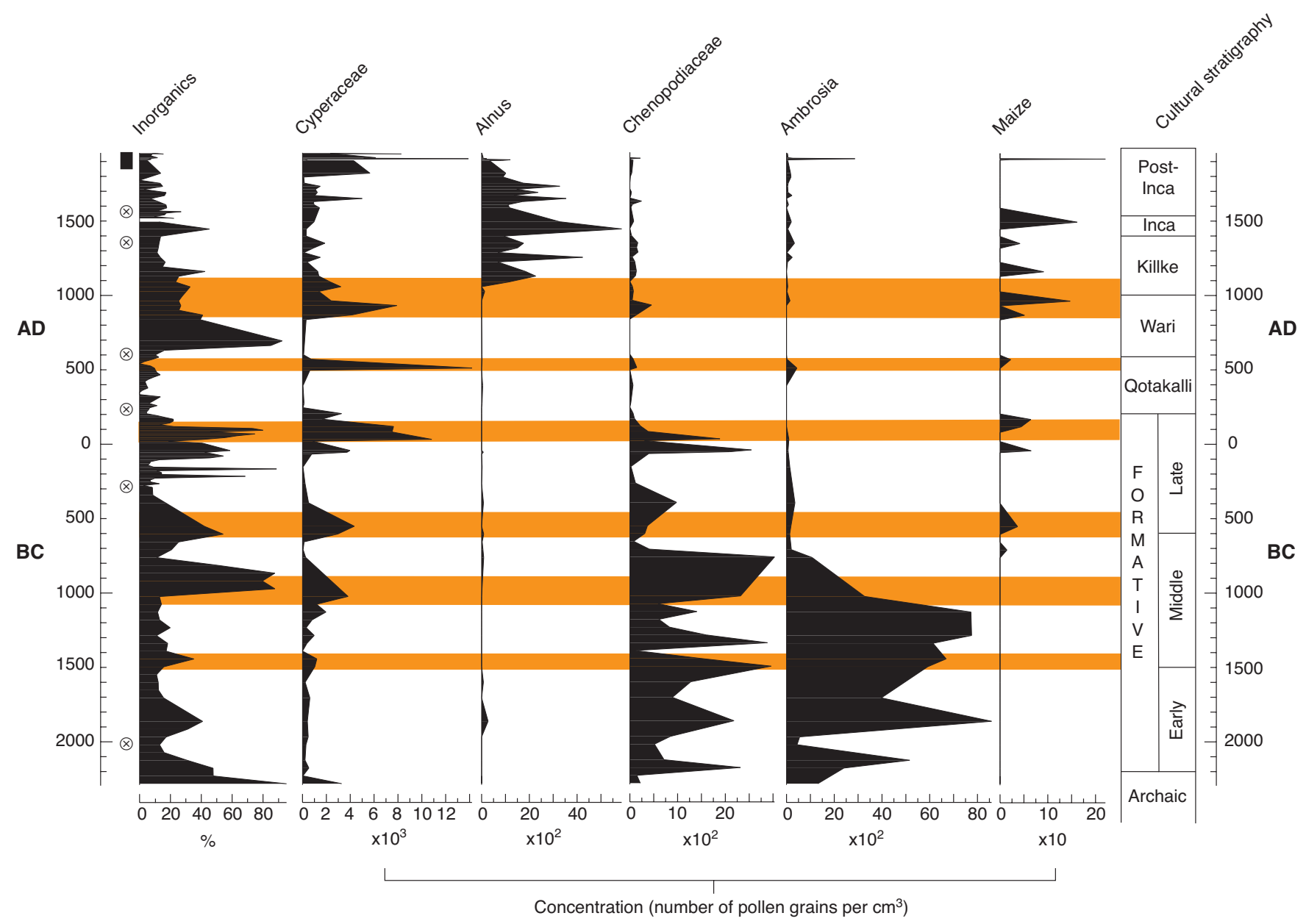

Fig. 3. Inorganic content (percentage) and pollen concentration diagram of selected taxa at Marcacocha plotted against age (adapted from Chepstow-Lusty et al., 2003). Filled rectangle indicates range of ${ }^{210} \mathrm{~Pb}$ dates (see Table 1); shaded circles indicate calibrated radiocarbon dates (see Table 2). The independently-derived archaeological chronology for the Cuzco region is also indicated (Bauer, 2004). Shaded horizontal bands denote periods of aridity as inferred from the Cyperaceae record (Chepstow-Lusty et al., 2003).

The range of $\delta^{13} \mathrm{C}$ values of phytoplankton is generally indistinguishable from the organic matter produced by terrestrial C3 plants $(-20$ to $-30 \%$ ). However, these values are usually markedly different from those obtained from material derived from both aquatic and terrestrial $\mathrm{C} 4$ plants (the latter including maize, some grasses and sedges), which are generally around -8 to $-13 \%$ (O'Leary, 1981, 1988). Under certain circumstances, however (such as a limitation of dissolved $\mathrm{CO}_{2}$ or conditions of high $\mathrm{pH}$ ), this apparently clear distinction between $\mathrm{C} 4$ and other plant sources breaks down and $\delta{ }^{13} \mathrm{C}$ values derived from $\mathrm{C} 3$ algal material can become as high as $-9 \%$, comparable with values obtained from $\mathrm{C} 4$ plant material (Meyers and Teranes, 2001). In addition, $\delta^{13} \mathrm{C}$ values derived from algal organic matter can also be unduly influenced by environmental factors such as soil erosion, the use of fertilisers or the presence of livestock sewage, all of which can potentially alter nutrient (principally nitrate and phosphate) delivery rates to the lake (Meyers and Teranes,
2001). Given these potential uncertainties in interpreting the ${ }^{13} \mathrm{C}$ signal, therefore, it is important to consider these data alongside other indicators of organic matter origin, such as $\mathrm{C} / \mathrm{N}$ ratios and plant macrofossil evidence.

\section{Methods}

Three sets of $1 \mathrm{~cm}^{3}$ volumetric sediment sub-samples were taken every centimetre throughout the top $1.9 \mathrm{~m}$ of the Marcacocha sequence, providing a ca. 6-year temporal resolution that spans the last 1200 years (assuming constant sedimentation rates).

\subsection{Plant macrofossils}

One set of sediment sub-samples was disaggregated in deionised water and macrofossils, including seeds and 


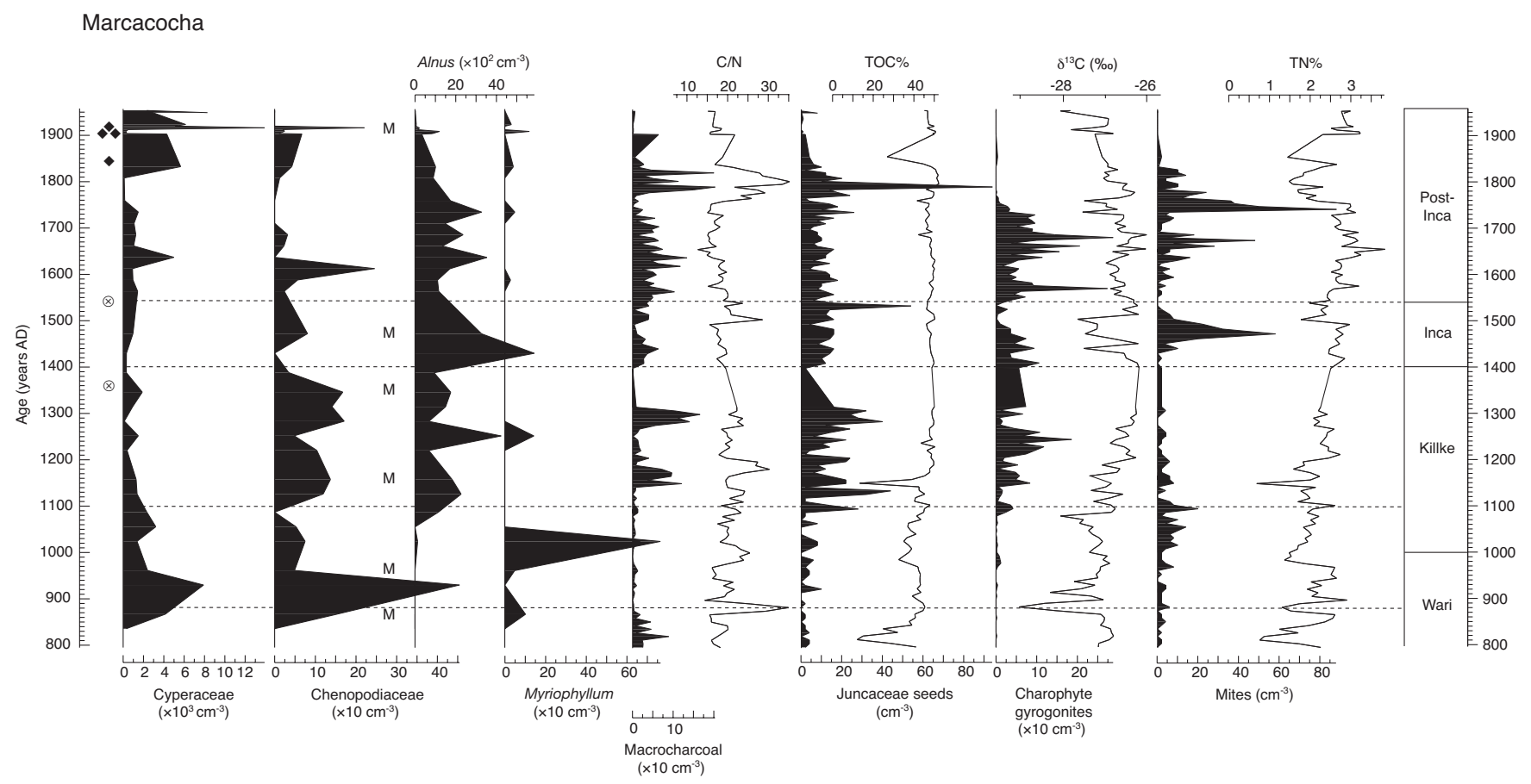

Fig. 4. Selected proxies and pollen taxa plotted against depth. Filled diamonds indicate ${ }^{210} \mathrm{~Pb}$ dates (see Table 1); shaded circles indicate calibrated radiocarbon dates (see Table 2). ' $M$ ' denotes occurrence of maize pollen; horizontal dashed lines delineate zones discussed in text. Absence of data in certain proxies between ca. AD 1320 and 1400 reflects where material sampled for radiocarbon dating is now missing (between 115 and $123 \mathrm{~cm}$ depth).

charophyte gyrogonites, were then hand-picked under a lowpower dissecting microscope (Fig. 4).

\subsection{Charcoal analysis}

A second set of sediment sub-samples was oxidized with $30 \%$ hydrogen peroxide in test tubes placed in a hot water bath at $60^{\circ} \mathrm{C}$ for $2-4 \mathrm{~h}$. The residue was then sieved and charcoal particles $>125 \mu \mathrm{m}$ counted using a low-power dissecting microscope. For analytical purposes, the raw charcoal accumulation rate data (C) were first interpolated to 7year time-steps, a value that corresponds approximately to the median temporal resolution of the entire charcoal record (Higuera et al., 2007, 2008) (Fig. 5a). The resulting interpolated data $\left(\mathrm{C}_{i}\right)$ were then separated into background $\left(\mathrm{C}_{b}\right)$ and peak $\left(\mathrm{C}_{p}\right)$ components (Fig. 5b). Low-frequency background variations in a charcoal record $\left(\mathrm{C}_{b}\right)$ represent changes in charcoal production, sedimentation, mixing and sampling, and are removed to obtain a residual series of "peak" events $\left(\mathrm{C}_{p}\right)$, i.e. $\mathrm{C}_{p}=\mathrm{C}_{i}-\mathrm{C}_{b}$ (Fig. $5 \mathrm{c}$ ). It is assumed that $\mathrm{C}_{p}$ itself comprises two sub-components: $\mathrm{C}_{\text {noise, }}$, representing variability in sediment mixing, sampling and analytical and naturally occurring noise; and $\mathrm{C}_{\text {fire }}$, representing charcoal input from local fire events (likely to be related to the occurrence of one or more local fires occurring within ca. $1 \mathrm{~km}$ of the site; Higuera et al., 2007). For each sample, a Gaussian mixture model was used to identify the $\mathrm{C}_{\text {noise }}$ distribution, the 99th percentile of which was then used to define a threshold separating samples into "fire" and "non-fire" events (Higuera et al., 2008). The $\mathrm{C}_{b}$ component was estimated by means of a locally-weighted regression using a 500-yr window; in all cases, the window width used was that which maximized the signal-to-noise index and the goodness-of-fit between the empirical and modelled $\mathrm{C}_{p}$ distributions. All numerical treatments were carried out using the CharAnalysis program (@ Philip Higuera). Fire history was described by quantifying the variation of fire return intervals (FRI, years between two consecutive fire events) over time, and smoothed using a locally-weighted regression with a 1000-yr window (Fig. 5d and e).

\subsection{Organic matter geochemistry}

${ }^{13} \mathrm{C} /{ }^{12} \mathrm{C}$ ratios were measured by combustion of the final set of sub-samples in a Carlo Erba 1500 elemental analyser online to a VG TripleTrap and Optima dual-inlet mass spectrometer, with $\delta^{13} \mathrm{C}$ values calculated to the VPDB scale using a within-run laboratory standard (BROC1) calibrated against NBS-19 and NBS-22. Replicate analysis of wellmixed samples indicated an absolute precision of $<0.1 \%$ o $(1 \sigma)$. Total organic carbon (\%TOC) and total nitrogen (\%TN) were also measured simultaneously (Fig. 4); these results were calibrated against an Acetanilide standard. \% TOC and $\% \mathrm{TN}$ can provide useful indicators, independently, of the 
a.

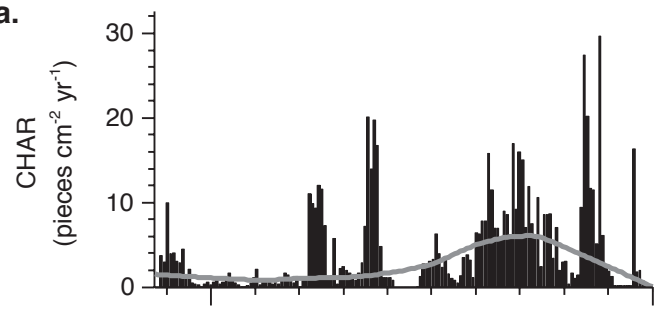

b.

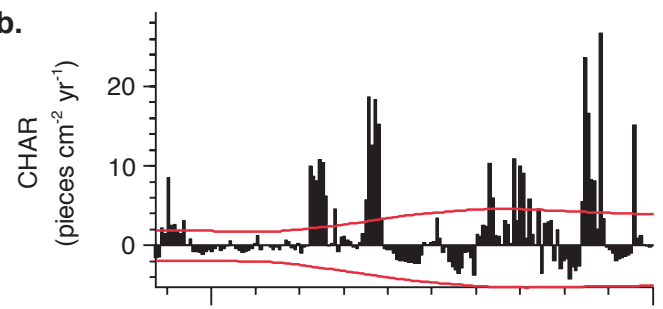

c.

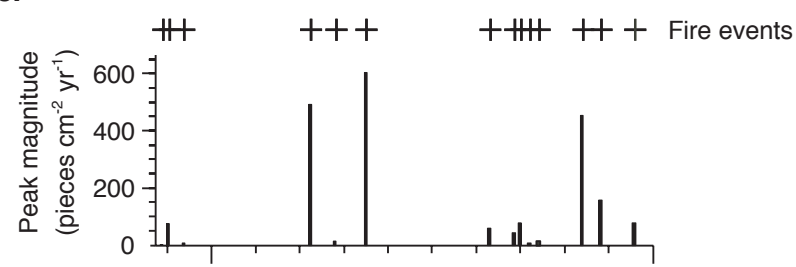

d.

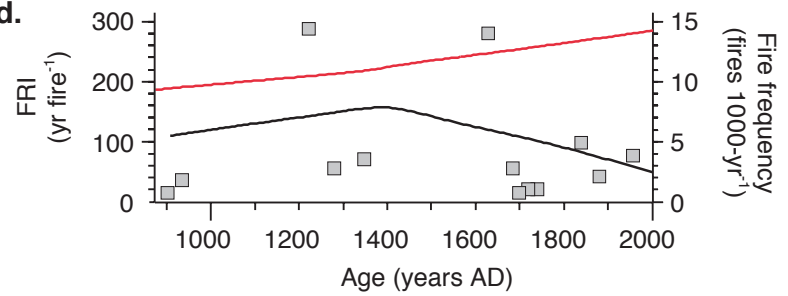

e.

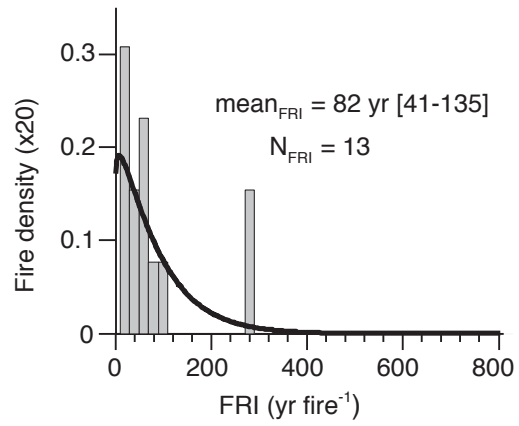

Fig. 5. Fire event reconstruction based on the raw charcoal accumulation rate (CHAR); see text for details. (a) represents the raw $\mathrm{CHAR}$ data interpolated to constant time intervals $\left(\mathrm{C}_{i}\right)$ using a 7-year running mean (black columns), with the background signal $\left(\mathrm{C}_{b}\right)$ also shown (grey line); (b) de-trended CHAR data (red lines denote threshold window, see text); (c) residual peaks and magnitude of detected fire events (+); (d) fire return interval (black line), inferred from time since last fire (grey squares), and simulated fire frequency (red line); (e) distribution of fire density. levels of inorganic sources from erosion and nutrients arising from livestock entering the lake. Replicate analysis of wellmixed samples indicated an absolute precision of $<0.1 \%$. $\mathrm{C} / \mathrm{N}$ ratios were calculated from $\% \mathrm{TOC}$ and $\% \mathrm{TN}$.

\subsection{Pollen analysis}

Full details of palynological sampling and preparation methodologies are given in Chepstow-Lusty et al. (2003), though are summarised here. Volumetric $1 \mathrm{~cm}^{3}$ sub-samples were taken every $4 \mathrm{~cm}$ (corresponding to a temporal resolution of ca. 40 years) and prepared for palynological analysis using standard procedures (after Method B of Berglund and Ralska-Jasiewiczowa, 1986). A Lycopodium tablet containing a known number of exotic spores was added to each sample allowing pollen concentrations to be calculated. Samples were left to stand overnight in hydrochloric acid $(\mathrm{HCl})$. Subsequent to washing in distilled water, the samples were placed in a hot water bath in $0.1 \mathrm{M}$ sodium pyrophosphate for 10-20 min to reduce clumping of the fine particles. After sieving at $125 \mu \mathrm{m}$, the samples were sieved through a $10 \mu \mathrm{m}$ mesh to remove the fine fraction (Bates et al., 1978). An additional oxidation technique was also used post-acetolysis to remove excess organic matter (Heusser and Stock, 1984). Pollen grains were counted to sums of 300 or more, except for 20 samples in which concentrations were especially low (particularly apparent in the lower part of the sequence), when a minimum sum of 100 grains was counted.

\section{Results}

New proxy data are plotted alongside selected pollen taxa in Fig. 4; the application of binary splitting techniques to all data (Birks and Gordon, 1985) suggests five main zones.

\subsection{Prior to AD 880}

At the very base of the sequence, this interval is notable only for its low pollen concentrations and the lowest \% TOC and $\% \mathrm{TN}$ than in any subsequent zone. $\mathrm{C} / \mathrm{N}$ ratios average ca. 18 , except at the very end of the zone, when they increase markedly to ca. $35 . \delta^{13} \mathrm{C}$ values also experience relative stability for most of the interval (ca. $-27 \%$ o), but this is followed by an abrupt decrease (to around -29\%o) at the end of the zone, in step with the positive shift in $\mathrm{C} / \mathrm{N}$. Analysis of the moderate-low concentrations of macrocharcoal suggests three significant fire events over this interval (Fig. 5c).

\subsection{AD 880-1100}

At ca. AD 880 an increase in Cyperaceae and Chenopodiaceae pollen concentrations is notable, followed by a marked decline through the rest of the interval; a much smaller, secondary peak occurs in Cyperaceae pollen concentrations towards the end of the zone. In contrast, pollen concentrations 
of the shallow water plant taxon Myriophyllum remain initially low, before undergoing expansion in the later part of this interval. $\mathrm{C} / \mathrm{N}$ ratios fall abruptly from their initial peak of ca. 35, to return to values oscillating around 20 for the rest of the zone. $\delta^{13} \mathrm{C}$ increases notably in a step-wise fashion at the beginning of the interval to reach pre-AD $880 \mathrm{lev}$ els, but then decreases once again (to ca. $-28 \%$ ) just before the end of the zone, when values once again recover to ca. $-27 \%$. Macrocharcoal and charophyte gyrogonite levels remain suppressed for most of the interval, whereas oribatid mite abundances show a gradual increase.

\subsection{AD 1100-1400}

High concentrations of Alnus pollen are noted for the first time from the very beginning of this interval. In addition, Juncaceae seeds become prominent, reflecting the importance of this family as a major component of the lakeside vegetation. Synchronously, charophyte oospores and macrocharcoal concentrations also increase notably, the latter providing evidence for three significant fire events during this interval (Fig. 5c). C/N ratios oscillate at values $>20$, whereas $\delta^{13} \mathrm{C}$ experiences a progressively positive trend, increasing by around $1 \%$ o from initial values of ca. $-27 \%$. There is a distinct but short-lived decline in \%TOC (of around $30 \%$ ) at ca. AD 1170 that is also mirrored by a similar event in the \% TN record.

\subsection{AD 1400-1540}

This interval is notable for the continued rise in Alnus pollen concentrations to the highest values in the sequence (peaking ca. AD 1450). This period also contains a significant decline in $\delta^{13} \mathrm{C}$ which, despite a variable signal, reaches a value of almost $-28 \%$ o before recovering at the very end of the zone. $\mathrm{C} / \mathrm{N}$ ratios also decline over this interval, but much more gradually. At the end of the zone, $\mathrm{C} / \mathrm{N}$ ratios also undergo a rapid increase from around 15 to almost 28, (seemingly leading the increase in $\delta^{13} \mathrm{C}$ slightly), before dropping back to ca. 20. This pattern is almost exactly the reverse of the \% TN signal. Oribatid mite concentrations undergo a marked rise in the second half of the interval, only then to decline suddenly. Macrocharcoal levels are, once again, relatively suppressed over this period.

\subsection{Post AD 1540}

Concentrations of Alnus pollen generally decline throughout this zone, which is generally the converse of Cyperaceae pollen concentrations, which increase notably from around AD 1800. Although Juncaceae seed and macrocharcoal concentrations remain relatively steady throughout, they both experience marked, short-lived peaks around AD 1780 (Juncaceae seed concentrations also briefly peaking around AD 1560). C/N ratios almost never dip below 15 throughout the entire zone, and they also experience a marked peak at ca. AD 1780. Interestingly, concentrations of charophytes and oribatid mite remains appear to co-vary inversely, with the principal mite peak (and minimum charophyte values) occurring ca. AD 1750. This interval is also characterised by the highest fire frequency of the entire record, with eight major fire events being identified (Fig. 5c).

\section{Interpretation and discussion}

\subsection{Prior to AD 880}

During much of the first millennium AD, the pollen record indicates little evidence for sustained agriculture at Marcacocha (see also Fig. 3). Indeed, Chenopodiaceae pollen, which probably includes a number of high altitude-favouring cultivars such as Chenopodium quinoa, is rare (ChepstowLusty et al., 2003), suggesting particularly suppressed, cool temperatures over this period. Furthermore, the sediments in this interval are characterised by a lower \% TOC than subsequent periods (colder climate, lower organic productivity), suggesting greater erosion in the immediate catchment, bringing in more inorganic material. Although human population levels would have been meagre, some anthropogenic disturbance is possible (as suggested by the minor peaks in charcoal at the top of this interval). More importantly, however, since plant growth would have been slow and the vegetation sparse, any natural or human agents would have enhanced erosion as the topsoil would have been less stable. An examination of the radiocarbon dates shows that the sedimentation rate is lower during this interval than the earlier part of the first millennium AD, so it is not necessarily as simple as equating higher erosion and greater inorganic input with a higher sedimentation rate. Values of $\mathrm{C} / \mathrm{N}>15$ indicate that erosion was also bringing in terrestrial organic matter, which, alongside $\delta^{13} \mathrm{C}$ values of around $-27 \%$, shows the dominance of $\mathrm{C} 3$ plants.

Independent evidence from ice core, archaeological, archaeobotanical and geomorphological data indicate that much of this period was characterized by relatively low temperatures, a factor that would have encouraged concentration of human populations at lower altitudes (Johannessen and Hastorf, 1990; Seltzer and Hastorf, 1990; Thompson et al., 1995; Kendall and Chepstow-Lusty, 2006). A period of burning close to the upper limit of this interval suggests that there may latterly have been limited anthropogenic activity in the basin (Figs. 4 and 5c).

\subsection{AD 880-1100}

An increase in Cyperaceae pollen concentrations at the beginning of this period probably reflects sedge colonization at the lake margin as the lake-level reduced in response to increasingly arid conditions (Chepstow-Lusty et al., 2003). This interpretation is supported by a major peak in $\mathrm{C} / \mathrm{N}$ and a corresponding minimum in $\delta^{13} \mathrm{C}$ (a combination indicative of 
abundant terrestrial plant material entering the lake from the catchment) and a short-lived peak in Chenopodiaceae pollen concentrations. This latter event (associated with the presence of maize pollen) indicates that increasing temperatures allowed limited agriculture (see Fig. 3 to compare the relative magnitude of this "peak" with that seen earlier in the record to emphasise the former importance of quinoa and related crops cultivated in this basin).

From around AD 1000, however, chenopods and sedges decline in importance at the expense of the shallow-water taxon Myriophyllum, which suggests low lake-levels and increasing levels of nutrients, possibly associated with greater livestock using the pasture. This interpretation is supported by several proxies, including the progressive increase of both $\mathrm{TN} \%$ and mite frequencies, and a decrease in $\delta^{13} \mathrm{C}$ values that, coupled with $\mathrm{C} / \mathrm{N}$ ratios of ca. 20 , suggest a significant C3 terrestrial input to the lake. Macrocharcoal levels remain suppressed throughout the zone (Figs. 4 and 5a-d), further implying that the basin was used for mostly pastoral purposes.

\subsection{AD 1100-1400}

The marked increase in Alnus pollen at the beginning of this interval reflects the rapid expansion into the immediate catchment (probably from lower altitudes) of Alnus acuminata. This is a tree species closely associated with the colonization of degraded soils and, subsequently, with agroforestry, because of its nitrogen-fixing properties, as well as its ability to grow fast and straight (Chepstow-Lusty and Winfield, 2000). This is the first sustained appearance of $\mathrm{Al}$ nus in the entire 4200-year record (Fig. 3), suggesting that the occasional pollen grains recorded prior to this are likely to represent long-distance transport. The notable increase in Juncaceae seeds indicate that lake-levels continued to drop, an interpretation supported by the rise in charophyte gyrogonites, a sustained increase in $\delta^{13} \mathrm{C}$ of around $+1 \%$ across the zone (possibly due to an increase in $\mathrm{C} 4$ plants in the catchment) and $\mathrm{C} / \mathrm{N}$ values generally in excess of 20 . Combined, these data all point to a significant rise in temperature, though without any concurrent increase in precipitation (the hydrological requirements of A. acuminata probably being met year-round by the adjacent, glacially-fed Patacancha River).

It is likely that a sustained warmer climate enabled human populations to return to traditional agricultural use of the Marcacocha Basin and the surrounding landscape, with pastoralism being pushed up to higher altitudes. Evidence of this is provided by the recovery of chenopod pollen concentrations, the presence of (rare) maize pollen and the decline in mite frequencies. Furthermore, heightened macrocharcoal values (Fig. 4) and the recognition of three significant fire events over this period (Fig. 5c) are likely to reflect increased burning and agricultural clearance. There is also evidence indicating the instigation of landscape transformation in the catchment; a brief yet marked reduction in \% TOC at around AD 1170 suggests destabilization of the landscape (possibly due to terrace building), causing an increase in inorganic material being deposited in the lake. Only after this construction phase was complete, would erosion have been reduced and the landscape stabilized, after which the lake sediments became highly organic and experienced very little inorganic input over the next 650 years or so (Donkin, 1979).

\subsection{AD 1400-1540}

This interval, which coincides with a period of rapid Inca expansion outside of the Cuzco heartland, appears to have been relatively stable from a climatic point of view. Temperatures seemed to have remained warm, with precipitation (and corresponding lake-levels) being low. Despite this climatic stability, significant land-use changes occurred in the basin. The increasing commercial importance of the Patacancha Valley caravan route is reflected in the sharp rise in mite abundances from the mid-1400s, suggesting an increased density of large herbivores (particularly llamas) in the catchment (Chepstow-Lusty et al., 2007). This interpretation is supported by an increase in \% TN, possibly related to higher levels of animal excreta originating from the lake margin. The influx of nutrients to the lake, coupled with likely disturbance generated by livestock, appears to have suppressed charophyte levels, which decline to almost zero by the end of the period. Low values of both $\mathrm{C} / \mathrm{N}$ (ca. 15) and $\delta^{13} \mathrm{C}$ (ca. - 28\%o) are suggestive of increased aquatic vegetation; when coupled with the reduced charophyte levels and higher Juncaceae seed concentrations, boggy marginal conditions may be inferred. Even though there is limited evidence for maize (a C4 plant) being grown in the basin, this crop requires good drainage and so was likely to have been grown away from the immediate lake catchment (as is the case today); only crops such as potatoes were/are cultivated in the areas liable to inundation. Furthermore, there is only muted evidence for sustained burning of the landscape over this interval (Figs. 4 and 5), suggesting either that there was only limited crop production in the basin at that time, and/or that soil fertility (often maintained by periodic firing after harvests) was instead sustained by the use of animal fertilizer. It is also noticeable that Alnus pollen concentrations reach their highest levels in the entire sequence, suggesting accelerated agroforestry around the basin; this species was one of the most economic and symbolically important trees for the Inca (Chepstow-Lusty and Winfield, 2000).

After about AD 1500, proxy signals at the very end of the zone witness some sharp shifts, including a marked decline in $\% \mathrm{TN}$ and mite frequencies, a recovery in $\delta^{13} \mathrm{C}$ values, a continuing decline in Alnus pollen and a notable peak in Juncaceae seeds. These changes are likely to be linked to the collapse of the Inca Empire and the corresponding abandonment of the basin and cessation of regular llama caravan activity. 


\subsection{Post AD 1540}

The marked recovery in charophyte gyrogonite concentrations at the beginning of this interval suggests a continuation of low lake-levels but a major decline in pasture usage. These inferences are supported by initially low mite abundances, declining $\mathrm{C} / \mathrm{N}$ values and a recovery in $\delta^{13} \mathrm{C}$ (to ca. $-26 \%$ ). A different world was imposed with the arrival of the Spanish. Against a backdrop of disease and falling population numbers, communities were often forced to migrate and/or compelled to work under the encomienda system (ChepstowLusty et al., 2007). Much of the previously cultivated landscape became rapidly overgrown and irrigation canals and terraces were no longer maintained, falling into neglect and disuse. A major part of the charcoal signal following the arrival of the Spanish (Fig. 4) probably represents the continual effort of the remaining population to clear agricultural land from rapidly colonizing shrubs and herbs.

Mite abundances undergo one final increase from around ca. AD 1600, which probably reflects the introduction of large domesticated herbivores from the Old World, such as sheep, cattle, goats and horses, into this part of the Patacancha Valley. This increased use of the basin for pasturing animals is supported by macrocharcoal concentrations (Fig. 5a-d), which show sustained and significant burning events (presumably for clearance purposes) just prior to, and throughout, the 17th century. A hiatus in burning activity during much of the following century coincides with the collapse and subsequent recovery of mite frequencies and, by inference, livestock populations. Historical documents report the arrival in about AD 1719-1720 of an epidemic (probably smallpox) which wiped out nearly all the indigenous people in the Patacancha Valley (Glave and Remy, 1983) and, at one point, is known to have killed 600 people in a single day in Cuzco (Esquivel y Navia, 1980). This event not only overlapped with the occurrence of four intense El Niño events (manifesting as strong droughts) between 1715 and 1736 (Carcelén Reluz, 2007), but also with the coldest conditions of the Little Ice Age (Thompson et al., 1988).

A resumption of landscape burning accompanies the final decline in mite populations throughout the 19th and 20th centuries (Figs. 5a-d). It is interesting to note that several independent regional reconstructions of biomass burning activity in South America show a decreasing fire frequency for the past 500 years and attribute this pattern to a range of climatic controls (e.g. Bush et al., 2008; Marlon et al., 2008; Nevle and Bird, 2008). The record at Marcacocha, however, shows the opposite trend (i.e. that fire frequency increases over this period; Fig. 5d), suggesting that it is local human activity influencing the fire history of the basin, and not climatic factors.

In the top part of the record, the decline of mites after ca. AD 1800 not only reflects a major drought (Tandeter, 1991; Gioda and Prieto, 1999), but also the subsequent infilling of the lake. The uppermost sediments (younger than ca.
AD 1830) consist of peats composed of wetland vegetation, dominated by Juncaceae; these no longer provide an environmental record comparable with the lake sediments below.

\section{A broader context}

The pattern of change witnessed at Marcacocha in the centuries that pre-dated the imperial expansion of the Inca can be summarized as: (1) a period of relative aridity developing from ca. AD 880, characterised by low lake-levels and a limited arable-based economy in the valley that gave way to more mixed agro-pastoralism at the beginning of the second millennium $\mathrm{AD}$; and (2) an interval of elevated temperatures from ca. AD 1100 that probably lasted for four centuries or more (the upper limit is difficult to define). This latter, warmer period is of particular interest, since it witnessed significant human presence in the basin in terms of agriculture, early landscape modification and later trading activity. In order to properly understand the broader-scale cultural and climatic conditions over this interval, it is necessary to assess the extent to which events happening in one Andean valley may have reflected what was happening regionally. In part, this can be achieved by comparison of the Marcacocha record with other, independently derived datasets.

The Quelccaya ice cap, located some $200 \mathrm{~km}$ to the southeast of Marcacocha at $5670 \mathrm{~m}$ asl in southern Peru, arguably provides the best-resolved climatic archive from the region (Thompson et al., 1984, 1986, 1988). Two overlapping cores, drilled though the ice to bedrock, provide a composite, annually-resolved record of the last 1500 years. While the use of proxies from this record as a yardstick for central Andean climatic variability is not without controversy (in particular, the complex relationships between $\delta^{18} \mathrm{O}$ variability and temperature, and ice accumulation and regional precipitation; Thompson et al., 1988; Grootes et al., 1989; Ortlieb and Macharé 1993; Gartner, 1996; Thompson et al., 2000; Calaway 2005), one unambiguous dataset from the Quelccaya record is that of dust content. At present, dust layers form annually on the surface of the glacier during the dry season, when dominantly southerly to north-westerly winds pick up material from the bare, recently-harvested agricultural areas of the Altiplano (Thompson et al., 1984, 1988). It has been postulated that the two most prominent dust events from the 1500-year Quelccaya record (centring on AD 600 and AD 920) may have their origin in anthropogenic activity, since they do not correspond with any marked climatic shifts.

The latter of these two prominent dust events lasts around 130 years and is characterized by a steady accumulation from AD 830 to a peak at AD 920, followed by a more rapid decline to about $\mathrm{AD} 960$. It has been suggested that this pattern may be linked with intensified raised field agriculture around Lake Titicaca (Thompson et al., 1988) and/or may be representative of a wider spectrum of human activity in the region, including terrace construction (Erickson, 2000). 
At Marcacocha, this interval is represented by high concentrations of Cyperaceae pollen, supported by high $\mathrm{C} / \mathrm{N}$ and low $\delta^{13} \mathrm{C}$ values, suggesting reduced lake-levels and a significant proportion of terrestrial plant matter entering the lake. Although no significant agricultural palynological indicators were found in the Quelccaya record to support the notion of anthropological activity within the landscape over this interval (Thompson et al., 1988), both chenopod (probably incorporating quinoa) and maize pollen are notable at Marcacocha, strongly suggesting agricultural use of the basin at this time.

It is also worth noting that some authorities have used the Quelccaya ice core data, as well as sediment records from Lake Titicaca that are indicative of low lake-levels, to infer a serious drought at ca. AD 1000-1100 (e.g. Thompson et al., 1988; Abbott et al., 1997; Binford et al., 1997). Furthermore, it is argued that this protracted period of aridity may (or may not) have been influential in hastening the demise of both the Tiwanaku and Wari cultures, centred on the southern shores of Titicaca and around Ayacucho, respectively (e.g. Binford et al., 1997; Erickson, 1999, 2000).

From the perspective of Marcacocha, the record there indicates that, although dry conditions began at least a century prior to ca. AD 1000 in the Cuzco region, temperatures remained suppressed at this time. These cooler conditions would have restricted the ability of cultures such as the Wari to exploit melt-water sustained higher altitudes for agricultural purposes. This contrasts markedly with conditions just a few hundred years later when, faced with similarly arid conditions, the Inca were able to take advantage of a warmer climate to exploit new, higher altitude agro-ecological zones and adapt their irrigation technologies to harness the yearround melt-water resources.

The rich archaeological record around Cuzco can also help in understanding the Marcacocha data over this crucial interval. It is from ca. AD 1200 (although perhaps as early as ca. AD 1000) that the Inca people in the Cuzco region are recognized archaeologically by the occurrence of Killke pottery (Rowe, 1944; Bauer, 2004). While there is a long history of human occupation in the Marcacocha area, there is a marked increase in the frequency of archaeological finds dated to after ca. AD 1000, such as those from the promontory of Juchuy Aya Orqo, adjacent to the lake (Kendall and Chepstow-Lusty, 2006; Kosiba 2006). This is corroborated by the Marcacocha charcoal record, which also suggests a notable increase in anthropogenic activity in the valley from ca. AD 1150. These data all point to a dramatic expansion and/or migratory influx of populations from lower altitudes over this interval, possibly accompanied by growth in economic activities. Such local trends reflect more widespread movements recorded across the Andean highlands at this time. Starting around AD 1000, regional settlement patterns shifted from valley floor and lower valley slopes to higher altitudinal locations (Arkush, 2006; Covey, 2008; Bauer and Kellett, 2009). By around AD 1300, however, the Marca- cocha area was directly incorporated into the growing Inca state and, by AD 1400, major imperial institutions had been established in the nearby town of Ollantaytambo. The incorporation of the area into the Inca state is reflected by the high oribatid mite concentrations, which suggest an increasing intensity of llama caravans utilizing the pasture adjacent to Marcacocha.

From an even broader perspective, the notion that temperatures were consistently higher than modern values during the 9th-14th centuries has received increasing attention in the Northern Hemisphere (Lamb, 1965; Hughes and Diaz, 1994). The prevailing view of this interval, known commonly as the "Medieval Warm Period" (MWP), is that elevated temperatures were often only intermittently experienced and, in some regions, was apparently characterized instead by climatic anomalies such as prolonged drought, increased rainfall or a stronger monsoon system (Hughes and Diaz, 1994; Stine, 1994; Bradley et al., 2003; Zhang et al., 2008). However, evidence for the MWP being a global phenomenon is contentious, especially in the Southern Hemisphere, where there are few continuous, detailed palaeoclimatic records spanning this interval (Bradley, 2000; Broecker, 2001). Nevertheless, from the Marcacocha dataset we can infer that temperatures increased from ca. AD 1100 (after a period of relative aridity in comparison to much of the first millennium $\mathrm{AD}$ ) and that conditions remained warm and stable for several centuries thereafter.

\section{Conclusions}

This study highlights some of the environmental and cultural changes that took place in the Cuzco region during the late period of prehistory. The scale of anthropological manipulation and transformation of the landscape in the south-central Andes appears to have increased after ca. AD 1100, probably in response to a climatic backdrop that was relatively warm, dry and essentially stable. The development of major irrigated terracing technology may have been increasingly necessary in these regions to obviate conditions of seasonal water stress, thereby allowing efficient agricultural production at higher altitudes. The outcome of these strategies was greater long-term food security and the ability to feed large populations. Such developments were exploited by the Inca of the Cuzco Valley, who were emerging as the dominant ethnic group of the region as early as ca. AD 1200. A healthy agricultural surplus supported their economic and political potential, enabling them to subjugate other local independent states and to effectively centralize power in the Cuzco region by ca. AD 1400 (Bauer, 2004).

Fully understanding the adaptive capacity-building strategies of the Inca in the face of demanding climatic conditions is still at an early stage. However, their success has clear implications for both rural and urban Andean communities 
facing the environmental challenges currently being posed by global warming.

Acknowledgements. We would like to thank the Palaeoenvironments Laboratory and the Centre of Bioarchaeology and Ecology at Montpellier University 2 for supporting this investigation, and gratefully acknowledge additional financial support from the CNRS and the French Ministry of Foreign Affairs. The Associación Ecosistemas Andinos (ECOAN) in Cuzco also provided invaluable facilities. We also thank K. Bennett for initiating the work at Marcacocha, A. Cundy (University of Brighton) for carrying out the ${ }^{210} \mathrm{~Pb}$ dating, A. Kendall and the Cusichaca Trust for providing logistical support, and A. Tupayachi Herrera, C. A. Chutas and S. Echegaray for additional field assistance. Two anonymous reviewers invested much time and effort to help us improve and widen the scope of this paper, for which we are grateful.

Edited by: D.-D. Rousseau

\section{References}

Abbott, M. B., Binford, M. W., Brenner, M., and Kelts, K. R.: A $3500{ }^{14} \mathrm{C}$ yr high resolution record of water-level changes in Lake Titicaca, Quat. Res., 47, 169-180, 1997.

Arkush, E. N.: Collapse, conflict, conquest: the transformation of warfare in the Late Prehispanic Andean highlands, in: The Archaeology of Warfare: Prehistories of Raiding and Conquest, edited by: Arkush, E. N. and Allen, M. W., University Press of Florida, Gainesville, USA, 286-335, 2006.

Arkush, E. N.: War, chronology and causality in the Titicaca basin, Lat. Am. Antiq., 19, 339-373, 2008.

Bates, C. D., Coxon, P., and Gibbard, P. L.: A new method for the preparation of clay-rich sediment samples for palynological investigations, New Phytol., 81, 459-463, 1978.

Bauer, B.: Ancient Cuzco: Heartland of the Inca, University of Texas Press, Austin, Texas, USA, 255 pp., 2004.

Bauer, B. and Kellett, L.: Cultural transformations of the Chanka heartland (Andahuaylas, Peru) during the Late Intermediate period (AD 1000-1400), Lat. Am. Antiq., in press, 2009.

Bawden, G.: The Moche, Blackwell Publishers, Cambridge, 392 pp., 1996.

Berglund, B. E. and Ralska-Jasiewiczowa, M.: Pollen analysis and pollen diagrams, in: Handbook of Holocene Palaeoecology and Palaeohydrology, Berglund, B. E. (Ed), John Wiley and Sons, Chichester, UK, 455-484, 1986.

Binford, M. W., Kolata, A. L., Brenner, M. Janusek, J. W., Seddon, M. T., Abbott, M. and Curtis, J. H.: Climate variation and the rise and fall of an Andean civilization, Quat. Res., 47, 171-186, 1997.

Birks, H.: Plant macrofossils, in: Tracking Environmental Change Using Lake Sediments: Volume 3, Smol, J. P., Birks, H. J. B. and Last, W. M. (Eds.), Kluwer Academic Publishers, Dordrecht, The Netherlands, 49-74, 2001.

Birks, H. J. B. and Gordon, A. D.: Numerical Methods in Quaternary Pollen Analysis, Academic Press, San Diego, California, USA, 317 pp., 1985.

Bradley, R.: Paleoclimate - 1000 years of climatic change, Science, 288, 1353-1354, 2000.
Bradley, R. S., Hughes, M. K., and Diaz, H. F.: Climate in Medieval time, Science, 302, 404-405, 2003.

Brenner, M., Whitmore, T. J., Curtis, J. H., Hodell, D. A., and Schelske, C. L.: Stable isotope $\left(\delta^{13} \mathrm{C}\right.$ and $\left.\delta^{14} \mathrm{~N}\right)$ signatures of sedimented organic matter as indicators of historic lake trophic state, J. Paleolimnol., 22, 205-221, 1999.

Broecker, W.: Was the Medieval Warm Period global?, Science, 291, 1497-1499, 2001.

Bush, M. B, Silman, M. R., McMichael, C., and Saatchi, S.: Fire, climate change and biodiversity in Amazonia: a Late-Holocene perspective, Philos. T. Roy. Soc. B, 363, 1795-1802, 2008.

Calaway, M. J.: Ice cores, sediments and civilization collapse: a cautionary tale from Lake Titicaca, Antiquity, 79, 778-790, 2005.

Carcelén Reluz, C. G.:. Idolatría indígena y devoción criolla como respuestas a la variabilidad climática en Lima y Huarochirí durante el siglo XVIII, Investigaciones Sociales, 11, 171-186, 2007.

Chepstow-Lusty, A. and Winfield, M.: Agroforestry by the Inca: lessons from the past, Ambio, 29, 322-328, 2000.

Chepstow-Lusty, A., Bennett, K. D., Fjeldså, J., Kendall, A., Galiano, W. and Tupayachi Herrera, A.: Tracing 4,000 years of environmental history in the Cuzco area, Peru, from the pollen record, Mt. Res. Dev., 18, 159-172, 1998.

Chepstow-Lusty, A., Bennett, K. D., Switsur, V. R., and Kendall, A.: 4000 years of human impact and vegetation change in the central Peruvian Andes - with events paralleling the Maya record?, Antiquity, 70, 823-833, 1996.

Chepstow-Lusty, A., Frogley, M. R., Bauer, B. S., Bush, M. B., and Tupayachi Herrera, A.: A late Holocene record of arid events from the Cuzco region, Peru, J. Quat. Sci., 18, 491-502, 2003.

Chepstow-Lusty, A., Frogley, M. R., Bauer, B. S., Leng, M., Cundy, A., Boessenkool, K. P., and Gioda, A.: Evaluating socioeconomic change in the Andes using oribatid mite abundances as indicators of domestic animal densities, J. Archaeol. Sci., 34, 1178-1186. 2007.

Covey, R. A.: How the Incas Built Their Heartland: State Formation and the Innovation of Imperial Strategies in the Sacred Valley, Peru, University of Michigan Press, Ann Arbor, USA, 333 pp., 2006.

Covey, R. A.: Multiregional perspectives on the archaeology of the Andes during the Late Intermediate period (c. A.D. 1000-1400), J. Archaeol. Res., 16, 287-338, 2008.

Donkin, R.: Agricultural Terracing in the Aboriginal New World, Viking Fund Publications in Anthropology 56, Wenner-Gren Foundation for Anthropological Research, New York, USA, 196 pp., 1979.

Erickson, C.: Neo-environmental determinism and agrarian 'collapse' in Andean prehistory, Antiquity, 73, 634-642, 1999.

Erickson, C.: The Lake Titicaca basin: a Precolumbian built landscape, in: Imperfect Balance: Landscape Transformations in the Precolumbian Americas, edited by: Lentz, D. L., Columbia University Press, New York, USA, 311-356, 2000.

de Esquivel y Navia, D.: Noticias cronológicas de la Gran Ciudad del Cuzco [1749]. Edición, prólogo y notas de F. Denegri Luna con la colaboración de H. Villanueva Urteaga y C. Gutiérrez Muñoz, Tomos 1 y 2, Fundación Augusto N., Lima, 1980.

Flynn, W. W.: Determination of low levels of polonium-210 in environmental materials, Anal. Chim. Acta, 43, 221-226, 1968. 
Gartner W. G.: Book review of 'The Tiwanaku: Portrait of an Andean Civilization' by A. L. Kolata, Ann. Ass. Am. Geog., 86, 153-156, 1996.

Gioda, A. and Prieto, M. R.: Histoire des sécheresses andines. La Météorologie, 8, 33-42, 1999.

Glave, L. M. and Remy, M. I... Estructura agraria y vida rural en una region andina: Ollantay'Tambo entre los siglos XVI y XIX, Archivos de Historia Andina, 3, Centro Bartolomé de las Casas, Lima, 584 pp., 1983.

Grootes, P. M., Stuiver, M., Thompson, L. G. and MosleyThompson, E.: Oxygen isotope changes in tropical ice, Quelccaya, Peru, J. Geophys. Res., 91, 1187-1194, 1989.

Hemming, J.: The Conquest of the Incas, Harcourt Brace Jovanovich, New York, USA, 641 pp., 1970.

Heusser, L. E. and Stock, C. E.: Preparation techniques for concentrating pollen from marine sediments and other sediments with low pollen density, Palynology, 8, 225-227, 1984.

Higuera, P. E., Brubaker, L. B., Anderson, P. M., Brown, T. A., Kennedy, A. T., and Hu, F. S.: Frequent fire in ancient shrub tundra: implications of paleorecords for Arctic environmental change, PLoS ONE, 3, e0001744, doi:10.1371/journal.pone.0001744, 2008.

Higuera, P. E., Peters, M. E., Brubaker, L. B., and Gavin, D. G.: Understanding the origin and analysis of sediment-charcoal records with a simulation model, Quat. Sci. Rev., 26, 1790-1809, 2007.

Hodell, D. A. and Schelske, C. L.: Production, sedimentation and isotopic composition of organic matter in Lake Ontario, Limnol. Oceanogr., 43, 200-214, 1998.

Hughes, M. K. and Diaz, H. F.: Was there a Medieval Warm Period, and if so, where and when?, Clim. Change, 26, 109-142, 1994.

Johannessen, S. and Hastorf, C.: A history of fuel management (AD 500 to the present) in the Mantaro Valley, Peru, J. Ethnobiology, 10, 61-90, 1990.

Kendall, A. and Chepstow-Lusty, A.: Cultural and environmental change in the Cuzco region of Peru: the rural development implications of combined archaeological and palaeoecological evidence, in: Kay Pacha: Cultivating Earth and Water in the Andes, edited by: Dransart, P., British Archaeological Reports International Series, 1478, 185-197, 2006.

Kolata, A. (Ed.): Tiwanaku and its Hinterland: Archaeology and Paleocology of an Andean Civilization, Vol. 1, Agroecology, Smithsonian Press, Washington DC, USA, 322 pp., 1996.

Kosiba, S. B.: Proyecto Arqueologico de la Subregion de Wat'a (PASW), Primera Temporada: Reconocimiento Intensivo del area Huarocondo - Ollantaytambo, Technical Report (Informe), Instituto Nacional de Cultura (INC), Cusco, 66 pp., 2006.

Krause, W.: Characeen als Bioindikatoren für den Gewässerzustand, Limnologica, 13, 399-418, 1981.

Kufel, L. and Kufel, I.: Chara beds acting as nutrient sinks in shallow lakes - a review, Aquat. Bot. 72, 249-260, 2001.

Lamb, H. H.: The early medieval warm epoch and its sequel, Palaeogeogr. Palaeocl., 1, 13-37, 1965.

Leng, M. J. and Marshall, J. D.: Palaeoclimate interpretation of stable isotope data from lake sediment archives, Quat. Sci. Rev., 23, 811-831, 2004.

Marlon, J. R., Bartlein, P. J., Carcaillet, C., Gavin, D. G., Harrison, S. P., Higuera, P. E., Joos, F., Power, M. J., and Prentice, I. C.: Climate and human influences on global biomass burning over the past two millennia, Nat. Geosci., 1, 697-702, 2008.
McCormac, F. G., Hogg, A. G., Blackwell, P. G., Buck, C. E., Higham, T. F. G., and Reimer, P. J.: SHCal04 southern hemisphere calibration 0-11.0 cal kyr BP, Radiocarbon, 46, $1087-$ 1092, 2004.

Meyers, P. A.: Preservation of elemental and isotopic source identification of sedimentary organic matter, Chem. Geol. (Isotope Geosci. Section), 114, 289-302, 1994.

Meyers, P. A. and Teranes, J. L.: Sediment organic matter, in: Tracking Environmental Change Using Lake Sediments: Volume 2, edited by: Last, W. M. and Smol, J. P., Kluwer Academic Publishers, Dordrecht, The Netherlands, 239-269, 2001.

Meyers, P. A., Leenheer M. J., and Bourbonniere, R. A.: Diagenesis of vascular plant organic matter components during burial in lake sediments, Aquat. Geochem. 1, 35-52, 1995.

Nevle, R. J. and Bird, D. K.: Effects of syn-pandemic fire reduction and reforestation in the tropical Americas on atmospheric $\mathrm{CO}_{2}$ during the European conquest, Palaeogeogr. Palaeocl., 264, 25 $38,2008$.

O'Leary, M. H.: Carbon isotope fractionation in plants, Phytochemistry, 20, 553-567, 1981.

O'Leary, M. H.: Carbon isotopes in photosynthesis, Bioscience, 38, 328-335, 1988.

Ortlieb, L. and Macharé, J.: Former El Niño events: records from western South America, Global Planet. Change, 7, 181-202, 1993.

Rowe, J. H.: An introduction to the archaeology of Cuzco, Papers of the Peabody Museum of American Archaeology and Ethnology, 27, Harvard University Press, Cambridge, USA, 70 pp., 1944.

Sarazin, G., Michard, G., Al Gharib, I., and Bernat, M.: Sedimentation rate and early diagenesis of particulate organic nitrogen and carbon in Aydat lake (Puy de Dome, France), Chem. Geol., 98, 307-316, 1992.

Seltzer, G. and Hastorf, C.: Climatic change and its effect on Prehispanic agriculture in the central Peruvian Andes, J. Field Archaeol., 17, 397-414, 1990.

Smith, C. S. and Barko, J. W.: Ecology of Eurasian watermilfoil, J. Aquat. Plant Manage., 28, 55-64, 1990.

Stanish, C.: Ancient Titicaca. University of California Press, Los Angeles, California, USA, 354 pp., 2003.

Stine, S.: Extreme and persistent drought in California and Patagonia during Medieval time, Nature, 269, 546-549, 1994.

Stuiver, M. and Reimer, P. J.: Extended 14C database and revised CALIB radiocarbon calibration program, Radiocarbon, 35, 215 230, 1993.

Talbot, M. and Lærdal, T.: The Late Pleistocene - Holocene palaeolimnology of Lake Victoria, East Africa, based upon elemental and isotopic analyses of sedimentary organic matter, Journal of Paleolimnology, 23, 141-164, 2000.

Tandeter, E.: La crisis de 1800-05 en el Alto Perú, Data, 1, 9-49, 1991.

Thompson, L. G., Davis, M. E., Mosley-Thompson, E., and Liu, K. -B.: Pre-Incan agricultural activity recorded in dust layers in two tropical ice cores, Nature, 307, 763-765, 1988.

Thompson, L. G., Mosley-Thompson, E., and Arnao, B. M.: El Niño-Southern Oscillation events recorded in the stratigraphy of the tropical Quelccaya ice cap, Peru, Science, 226, 50-53, 1984.

Thompson, L. G., Mosley-Thompson, E., Dansgaard, W., and Grootes, P. M.: The Little Ice Age as recorded in the stratigraphy of the tropical Quelccaya ice cap, Science, 234, 361-364, 
1986.

Thompson, L. G., Mosley-Thompson, E., Davis, M. E., Lin, P. N., Henderson, K. A., Cole-Dai, J., Bolzan, J. F., and Liu, K.-B: Late glacial stage and Holocene tropical ice core records from Huascaran, Peru, Science, 269, 46-50, 1995.

Thompson, L. G., Mosley-Thompson, E., and Henderson, K. A.: Ice-core palaeoclimate records in tropical South America since the Last Glacial maximum, J. Quat. Sci., 15, 377-394, 2000.

Williams, P. R.: Rethinking disaster-induced collapse in the demise of the Andean highland states: Wari and Tiwanaku, World Archaeol., 33, 361-374, 2002.

Williams, P. R.: Agricultural innovation, intensification and sociopolitical development: the case of highland irrigation agriculture on the Pacific Andean watersheds, in: Agricultural Strategies, edited by: Marcus, J. and Stanish, C., Cotsen Institute of Archaeology, UCLA, 309-333, 2006.
Whitlock, C. and Larsen, C. P. S.: Charcoal as a fire proxy, in: Tracking Environmental Change Using Lake Sediments: Volume 3, edited by: Smol, J. P., Birks, H. J. B. and Last W. M., Kluwer Academic Publishers, Dordrecht, The Netherlands, 75-97, 2001.

Zhang, P., Cheng, H., Edwards, R. L., Chen, F., Wang, Y., Yang, X., Liu, J., Tan, M., Wang, X., Liu, J., An, C., Dai, Z., Zhou, J., Zhang, D., Jia, L., and Johnson, K. R.: A test of climate, sun and culture relationships from an 1810-year Chinese cave record, Science, 322, 940-942, 2008. 